\title{
Effects of defoliation on the frost hardiness and the concentrations of soluble sugars and cyclitols in the bark tissue of pedunculate oak (Quercus robur L.)
}

\author{
Frank M. THOMAS ${ }^{\mathrm{a} *}$, Gabriele MEYER $^{\mathrm{a}}$, Marianne POPP \\ a Department of Plant Ecology, Albrecht von Haller Institute of Plant Sciences, University of Göttingen, Untere Karspüle 2, 37073 Göttingen, Germany \\ b Department of Chemical Physiology of Plants, Institute of Ecology and Conservation Biology, University of Vienna, Althanstraße 14,
} 1090 Vienna, Austria

(Received 9 July 2003; accepted 26 September 2003)

\begin{abstract}
As a measure of frost hardiness, we determined an index of injury $\left(I_{-30}\right)$ in living bark tissue of 20-year-old pedunculate oaks (Quercus robur L.) that had been manually and almost completely defoliated in the first half of May of one or two years, and of non-defoliated control trees. $I_{-30}$ was calculated as a percentage value on the basis of electrolyte leakage from samples artificially frozen at a temperature of $-30{ }^{\circ} \mathrm{C}$, and from unfrozen control samples. In parallel, the bark's concentrations of soluble sugars, of nitrogen and of quercitol, a cyclic polyol, were measured. Repeated defoliation significantly reduced the frost hardiness of the bark as well as its concentrations of raffinose, stachyose, nitrogen and quercitol. The $I_{-30}$ values were correlated with the total concentration of soluble sugars and with the concentrations of the individual sugar compounds, but not with the quercitol concentration. Less tight, yet significant correlations were obtained between $I_{-30}$ and nitrogen concentrations. We conclude that repeated defoliation decreases the bark's capability to acclimatize to winter frost due to a reduction in the concentrations of soluble sugars, particularly those of raffinose and stachyose.
\end{abstract}

electrolyte leakage / oak decline / quercitol / raffinose / stachyose

Résumé - Effets de la défoliation sur la résistance au gel et les concentrations de sucres solubles et de cyclitols dans le liber de chênes pédonculés (Quercus robur L.). Comme mesure de la résistance au gel du liber vivant de chênes pédonculés âgés de vingt ans et ayant déjà été défoliés manuellement presque entièrement dans la première moitié du mai d'une ou deux années, on a calculé un index de dommage $\left(I_{-30}\right)$ et on a comparé avec la valeur correspondante d'arbres témoins non défoliés. On a déterminé $I_{-30}$ comme une valeur de pourcentage sur la base de perte d'électrolytes des échantillons congelés artificiellement à $-30^{\circ} \mathrm{C}$, et des échantillons pas congelés. Parallèlement on a mesuré les concentrations de sucres solubles, d'azote et de quercétol, un polyalcool cyclique, du liber. La deuxième défoliation a réduit de manière significative tant la résistance au gel du liber que ses concentrations en raffinose, stachyose, azote et quercétol. Les indices de dommage $\left(I_{-30}\right)$ étaient en corrélation avec la concentration totale de sucres solubles et avec les concentrations de sucres individuels, mais pas avec la concentration de quercétol. Des corrélations moins étroites mais toutefois significatives ont été mises en évidence entre les valeurs $I_{-30}$ et les concentrations d'azote. Ces résultats nous permettent de conclure qu'une défoliation répétée réduit la capacité d'acclimatation du liber aux gels d'hiver en raison d'une diminution des concentrations de sucres solubles, surtout de raffinose et de stachyose.

dépérissement du chêne / perte d'électrolytes / quercétol / raffinose / stachyose

\section{INTRODUCTION}

In contrast to the beech (Fagus sylvatica L.), which is the other most important Central-European deciduous forest tree species, the pedunculate oak (Quercus robur L.) and sessile oak (Q. petraea [Matt.] Liebl.) are normally subject to several severe defoliation events, including complete defoliation (>90\%), during their life cycles. On average, defoliation occurs at least once per decade [18]. However, complete defoliation in two or more consecutive years may also occur, and can exert severe stress to the trees due to great loss of photosynthate. Several investigations have supplied evidence that severe or complete defoliation by lepidopteran larvae plays a predominant role in the occurrence of increased oak mortality ("oak decline") in various regions of Europe (e.g., [19, 25, 36,41]).

Defoliation results in alterations in the trees' carbohydrate levels. In twigs, trunks and fine roots of young poplars (Populus $\times$ canadensis), the concentrations of total non-structural carbohydrates were lower in the weeks following defoliation in spring and early summer [24]. In oaks, defoliation leads to substantially

\footnotetext{
* Corresponding author: fthomas@gwdg.de
} 
reduced starch and sucrose contents in the roots, but to increased concentrations of fructose and glucose in the cambial zone of the bark [50].

In most cases, repeated defoliation alone is not sufficient to trigger increased oak mortality, but has to be accompanied by additional stress factors. Extreme summer droughts and severe winter frosts are the most important ones of these factors. In oaks, extremely low winter temperatures (down to $-26^{\circ} \mathrm{C}$ ) were found to cause necroses in the living bark tissue of the trunks, and obviously represented one of the factors that resulted in an episode of oak decline in Northern Germany [19].

Generally, the seasonal development of frost hardiness is closely linked to photoperiod, temperature and to the tissues' concentrations of soluble sugars $[2,15,26,38]$. This has also been shown for the bark tissue of several deciduous tree species [33]. Other components that have been related to frost hardiness are cyclitols (isocyclic polyols) and nitrogen $(\mathrm{N})$ compounds [27, 38, 51]. In $Q$. robur, quercitol (L-1,3,4/2,5-cyclohexanepentol) is the predominant cyclitol [35]. A significant reduction in the concentration of quercitol of bark tissue was found in 21-year-old sessile oaks (Q. petraea [Matt.] Liebl.), after a single manual defoliation in June, in the following winter [16]. Recently, some cyclitols, including quercitol, have been shown to decrease damage induced by a freeze-thaw cycle in thylakoid membranes [32].

A combination of severe defoliation in at least two consecutive years with climatic extremes such as severe winter frost can be presumed to be the most significant factor complex in the occurrence of oak decline in Central Europe [18, 47]. Preliminary investigations had shown that, in tendency, the frost hardiness of bark from pedunculate and sessile oaks was reduced in winter after insect defoliation in the preceding spring [45]. However, these investigations could only be conducted on a limited number of trees and sampling dates. Consequently, a more thorough study was initiated, which included a larger number of trees that had been manually defoliated once or twice before beginning the determination of frost hardiness. We hypothesize that complete defoliation of oaks in the spring - especially when occurring in consecutive years - reduces the frost hardiness of the bark in the following winter via a reduction in the content of soluble sugars and/or cyclitols. To obtain preliminary indications on the role of nitrogen compounds in a defoliation-induced decrease in frost hardiness, the nitrogen concentration and the $\mathrm{C}: \mathrm{N}$ ratios of the bark tissue were included in the study.

\section{MATERIALS AND METHODS}

\subsection{Study site, plant material and defoliation}

The investigated pedunculate oaks (Quercus robur L.) grew on loamy sand on the ground of a tree nursery near the village of Wietze in the southern heath land of Lower Saxony (NW Germany; N 52 39', E $09^{\circ} 50^{\prime} ; 30 \mathrm{~m}$ a.s.1.). They had been grown from acorns originating from the Netherlands ("NLA Selektion Holland 0-100 m"). In Mai 2000 , the trees were 20 years old and grew on an open field, in a row exposed to the North-Northeast with a length of $300 \mathrm{~m}$ from the first to the last investigated tree. The distance between the trees, which were

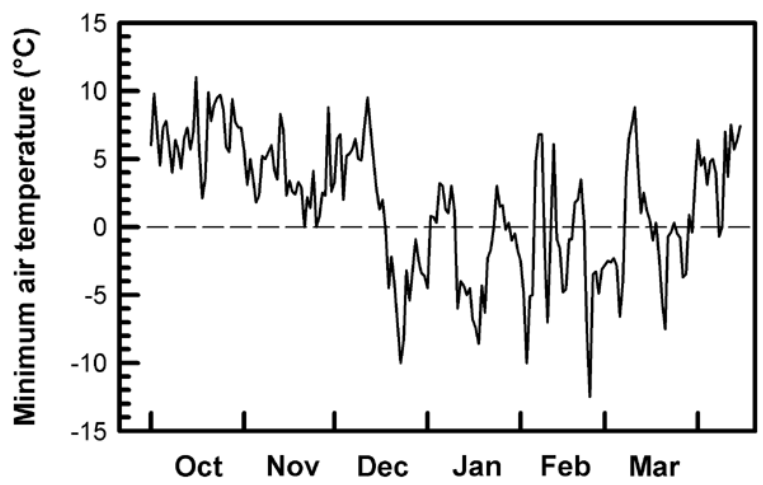

Figure 1. Daily minimum air temperature in the region of the investigation site during the sampling period in winter 2000/2001.

approximately $5 \mathrm{~m}$ high, was about $3 \mathrm{~m}$. Since 1997, the area had been excluded from the nursery's fertilization scheme.

In the region of the nursery, the mean annual temperature is $8.9^{\circ} \mathrm{C}$, and the mean annual precipitation, $654 \mathrm{~mm}$ (average for the period 1960-1990; data from the meteorological station of Celle-Wietzenbruch, $\mathrm{N} 52^{\circ} 38^{\prime}, \mathrm{E} 10^{\circ} 01^{\prime} ; 39 \mathrm{~m}$ a.s.1.; $16 \mathrm{~km}$ southeast of the nursery). For the sampling period, the daily minimum air temperatures (Fig. 1) were obtained from the meteorological station at Unterlüß (N 52 ${ }^{\circ} 51^{\prime}, \mathrm{E} 10^{\circ} 17^{\prime}$; $95 \mathrm{~m}$ a.s.l.), which is located in the same climatic region, $38 \mathrm{~km}$ to the northeast of the nursery, and is operated by the German Meteorological Service [12].

To exclude possible position effects, six groups consisting of three oaks of the same height and the same habit, which were growing in close vicinity, were selected from the tree row. Within each group, each tree was randomly assigned to one of the following three treatments (to give a total number of six trees per treatment): control $(\mathrm{C}$; no defoliation), single defoliation (SD; in May 2000), or repeated defoliation (RD; in May 1999 and 2000). Defoliation was performed in the first half of May, after budbreak, by manually stripping the leaves from the shoots. The extent of defoliation was 90-95\%. Only the uppermost shoots that could not be reached with ladders remained non-defoliated. The intensity and timing of this treatment mimicked a complete defoliation by larvae of Tortrix viridana L. [29], a lepidopteran species that belongs to the most important oak-defoliating insects in Central Europe [47].

\subsection{Determination of growth and sampling}

In May 2000, the circumference of the tree stems was measured. To determine the radial stem growth increment, the measurement was repeated in March 2001.

In 2000, leaf samples were taken in mid-July, during the regular period of leaf sampling from broadleaved trees in German forest monitoring [8]. At that time, the defoliated trees had restored their canopies through the formation of replacing shoots (canopy restoration was completed by the end of June, as was assessed by visual inspection). From each tree, three shoots were harvested from the upper crown, and were combined to form one sample per tree. The leaves were placed in plastic bags and put on dry ice in a cool box for transportation. In the laboratory, they were stored at $-18{ }^{\circ} \mathrm{C}$ until further processing.

On eight dates, from October 2000 to April 2001, samples of the living bark were taken at breast height from the north-northeasterly exposed side of the stems with a cork borer (10 mm diameter). Remnants of cambium and dead bark (rhytidome) were removed with a scalpel. The samples were placed in glass vials closed with screw caps. 
For transportation, they were stored, immediately after sampling, in a cool box at $+5{ }^{\circ} \mathrm{C}$ (for the determination of frost hardiness and freezing injury), or on dry ice (for chemical analyses). In the laboratory, the samples were kept at $+5^{\circ} \mathrm{C}$ in a refrigerator until the determination of frost hardiness and freezing injury on the following day, or at $-18^{\circ} \mathrm{C}$ until chemical analyses.

\subsection{Frost hardiness and freezing injury}

Frost hardiness of the bark tissue was determined by artificial freezing according to Kolb et al. (1985) [23], modified according to Thomas and Ahlers (1999) [44]. The glass vials with one bark sample each were frozen in a cryostat (Fryka FT 10-44; National Lab., Mölln, Germany) from $+5{ }^{\circ} \mathrm{C}$ to $-30{ }^{\circ} \mathrm{C}$ with a cooling rate of $5{ }^{\circ} \mathrm{C} \cdot \mathrm{h}^{-1}$ (extreme minimum air temperatures below $-25^{\circ} \mathrm{C}$ had occasionally occurred in Northern Germany during the past decade). After being kept at $-30^{\circ} \mathrm{C}$ for $30 \mathrm{~min}$, the samples were allowed to thaw overnight in a refrigerator at $+5{ }^{\circ} \mathrm{C}$. Two replicates were used per tree and sampling date. A respective number of control samples remained unfrozen in a refrigerator at $+5{ }^{\circ} \mathrm{C}$ during that time. Electrolyte leakage from the samples was measured with a conductivity sensor (sensor LTA 1 and conductometer LF 2000/C; WTW, Weinheim, Germany) after incubation in $6 \mathrm{~mL}$ of $3 \%(\mathrm{v} / \mathrm{v})$ propanol in distilled water for $24 \mathrm{~h}$. The relative conductivity $(R C ; \%)$ of the medium was determined after killing the tissue by autoclaving as described by Thomas and Ahlers (1999) [44]. From the $R C$ values of frozen and control samples, an index of injury by freezing at $-30{ }^{\circ} \mathrm{C}\left(I_{-30}\right)$ was calculated according to Flint et al. (1967) [13]. The maximum range of this index was $0 \%$ (no freezing injury) to $100 \%$ (tissue completely killed by freezing). Low index values indicate high frost hardiness and vice versa.

For the determination of this index of injury, we could rely on only one freezing temperature $\left(-30^{\circ} \mathrm{C}\right)$ for the following reasons. First, most of the previous measurements had shown that, in bark tissue from oaks, a linear relationship exists between the index of injury and freezing temperatures ranging from $-5{ }^{\circ} \mathrm{C}$ to $-30{ }^{\circ} \mathrm{C}[45,46]$. Second, temperatures of $-25^{\circ} \mathrm{C}$ and $-30{ }^{\circ} \mathrm{C}$ - with the above-mentioned procedure for cooling, duration of exposure to freezing temperature, and thawing - were shown to be sufficiently low for the detection of differences in frost hardiness of bark tissue obtained from trees subjected to different treatments or conditions, including defoliation history [44-46]. And third, with those freezing temperatures, the course of hardening and dehardening of bark tissue from oaks during winter can be revealed $[44,46]$.

In order to test whether the actual air temperatures during winter did cause any injury to the bark tissue of the trees, the possible freezing injury was determined according to Murray et al. (1989) [30], modified according to Thomas and Ahlers (1999) [44]. Three replicates per tree and sampling date were incubated with $10 \mathrm{~mL}$ of $0.5 \%(\mathrm{v} / \mathrm{v})$ propanol (in distilled water), and the conductivity of the medium was measured 11 times starting at $0.5 \mathrm{~h}$ and ending at $144.5 \mathrm{~h}$ after the start of incubation. Between the measurements, the samples were kept in a refrigerator at $+5^{\circ} \mathrm{C}$. Before each measurement, they were brought to room temperature. After the last measurement, the tissue was killed by autoclaving, and the $R C$ was determined for each time of measurement as described above. The log values of $R C$ were plotted against the log values of time (hours), and the slopes of the regression lines $(b)$ were computed. A mean $b$ value was calculated for each tree and sampling date. Higher $b$ values indicate increased freezing injury.

\subsection{Chemical analyses}

The leaf and bark samples were lyophilized at $-48^{\circ} \mathrm{C}$ for four days and pulverized. The $\mathrm{N}$ concentrations were measured, in one sample per tree and sampling date, with a CHNOS-analyzer (vario EL III, Elementar-Analysensysteme, Hanau, Germany), with acetanilide as a standard. For the determination of soluble sugars and cyclitols, $20 \mathrm{mg}$ of the lyophilized and pulverized bark material from the control and the repeatedly defoliated oaks (one sample per tree and sampling date) were extracted for $30 \mathrm{~min}$ with water at $100{ }^{\circ} \mathrm{C}$ and centrifuged. The supernatant was dried in a vacuum, and $200 \mu \mathrm{L}$ pyridine and $50 \mu \mathrm{L}$ of a mixture of N,O-bis(trimethylsilyl)-trifluoracetamide (BSTFA) and trimethylchlorosilane (volume combination $9+1$ ) were added. For silylization, the samples were heated for $60 \mathrm{~min}$ at $75^{\circ} \mathrm{C}$. The analyses were made with a gas chromatograph (HP 6890, column: HP 5 MS). The injected sample volume was $0.5 \mu \mathrm{L}$. The temperature profile was as follows: $85^{\circ} \mathrm{C}$ for $1 \mathrm{~min}$, heating to $240{ }^{\circ} \mathrm{C}$ with $8{ }^{\circ} \mathrm{C} \cdot \mathrm{min}^{-1}$, heating from $240{ }^{\circ} \mathrm{C}$ to $325^{\circ} \mathrm{C}$ with $12^{\circ} \mathrm{C} \cdot \mathrm{min}^{-1}$. The measurement was performed with an FID detector at $330^{\circ} \mathrm{C}$. The internal standard was phenyl- $\beta$-D-glucopyranoside. The following soluble sugars were determined: fructose, glucose, raffinose, stachyose and sucrose; and the following cyclitols: myo-inositol (4,6/1,2,3,5-cyclohexanehexol), quercitol (L-1,3,4/2,5-cyclohexanepentol) and viburnitol (2,4/3,5,6cyclohexanepentol). These compounds were selected because they have previously been reported to occur in larger quantities in the bark of oaks (fructose, glucose, sucrose, myo-inositol, quercitol, viburnitol $[16,35])$, or to be related to the frost hardiness of the bark or stem of woody species (raffinose, stachyose [33, 43]). The identity of the cyclitols was established by comparison with previously isolated standards [32].

\subsection{Statistics}

In the presentation of the results, means \pm 1 standard error are given. The data sets were tested on normal distribution using the UNIVARIATE procedure of SAS 8.1 (SAS Institute, Cary, NC, USA) and the distribution of the $W$ values [40] (significance level $P<0.1$ ). The glucose concentration data were not normally distributed; thus, differences between the treatments (control and repeated defoliation) on the individual dates were tested using the non-parametrical $U$ test [37] $(P<0.05)$. In all other cases, the data were normally distributed, and one-way ANOVA (growth increment, foliar nutrient relations) or oneway ANOVA with repeated measurement analysis (frost hardiness, freezing injury, chemical analyses of bark samples; independent variables: defoliation treatment and date) was employed (GLM procedure; SAS 8.1), followed by Tukey's test $(P<0.05)$. Regressions were performed with the REG procedure (SAS 8.1), and the regression coefficients were tested on significance using the $t$-test [37]. Multiple regressions on $I_{-30}$ as the dependent variable, with the single sugar concentrations, the total sugar concentration, the nitrogen and quercitol concentrations and $\mathrm{C}: \mathrm{N}$ ratios of the bark and the defoliation as the predictor variables, were conducted with the RSQUARE procedure (SAS 8.1). The significance of the multiple determination coefficients $R^{2}$ and the significance of the increase in $R^{2}$ by including additional variables into the model were tested using the distribution of $F$ values [37].

\section{RESULTS}

\subsection{Growth increment, freezing injury and frost hardiness}

In May 2000, at the time of the second defoliation of the RD treatment, the diameter at breast height of the oak stems was $10.8 \pm 0.8,11.0 \pm 0.5$ and $10.2 \pm 0.7 \mathrm{~cm}$ in the treatments $\mathrm{C}$, $\mathrm{SD}$ and $\mathrm{RD}$, respectively. The diameters did not differ significantly among the treatments. In March 2001, ten months after the last defoliation treatment, the relative growth increment of the control trees' stems was significantly higher than that of the SD and RD oaks; whereas no significant difference was detected between the two defoliation treatments (Tab. I). 
Table I. Relative growth increment of stem diameter, foliar N concentration and foliar C:N ratio of 20-year-old (in 2000) pedunculate oaks subjected to different defoliation treatments. Different letters indicate significant differences among the treatments.

\begin{tabular}{lccc}
\hline Period or time of measurement & \multicolumn{2}{c}{ Treatment } \\
\cline { 2 - 4 } & Control & Single defoliation & Repeated defoliation \\
\hline $\begin{array}{l}\text { Relative stem growth increment (\%) } \\
\text { May 2000-March 2001 }\end{array}$ & $7.2 \pm 1.2 \mathbf{a}$ & $1.9 \pm 0.4 \mathbf{b}$ & $1.2 \pm 0.3 \mathbf{b}$ \\
Foliar N concentration (mg.g ${ }^{-1}$ D.M.) & & & $21.7 \pm 0.8$ \\
July 2000 & $22.8 \pm 1.0$ & $25.0 \pm 1.3$ & $21.4 \pm 0.9$ \\
Foliar C:N ratio (g.g-1 D.M.) & & $18.7 \pm 0.9$ & \\
July 2000 & $20.4 \pm 0.9$ & & \\
\hline
\end{tabular}

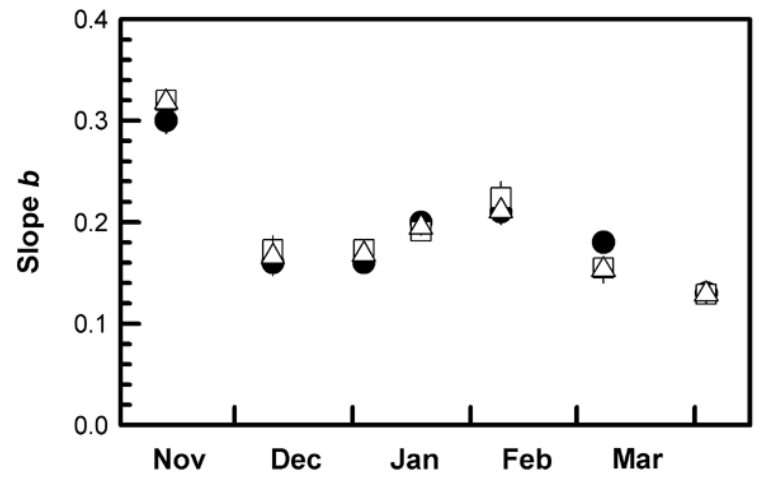

Figure 2. Freezing injury caused by actual air temperatures to bark tissue of 20-year-old pedunculate oaks subjected to different treatments (closed circles, control; open squares, single defoliation; open triangles, repeated defoliation). The freezing injury was determined as the slope $b$ of the linear relationships between the log values of relative conductivity $(R C ; \%)$ of the incubation solution and the duration of bark tissue incubation (h) during the investigation period. The slope is a relative measure of freezing injury, and is used here for a comparison among the defoliation treatments (see text for details).

Data on freezing injury and frost hardiness are given for a period extending from the beginning of November (when the daily minimum air temperature in the region was below $+5{ }^{\circ} \mathrm{C}$ on three consecutive days for the first time in that winter) to the beginning of April (after air temperatures lower than $-1{ }^{\circ} \mathrm{C}$ had occurred for the last time-i.e., on March 28 -in that winter; cf. Fig. 1).

The frost periods during the investigation period (absolute minimum: $-12.5^{\circ} \mathrm{C}$ ) were not severe enough to induce differences in freezing injury of the bark tissue among the treatments as was obvious by the lack of significant differences in the slope $b$ (Fig. 2).

The method employed to assess the frost hardiness of the bark tissue (determination of an index of injury) was suitable to reveal the periods of frost hardening (in late autumn) and dehardening (in late winter; Fig. 3). Compared to the control trees, the frost hardiness of the bark tissue of the repeatedly defoliated trees was significantly reduced. This was true for a comparison considering the entire investigation period as well as for a comparison on one single date in late winter (first half of February; Fig. 3). The frost hardiness of the bark of the SD

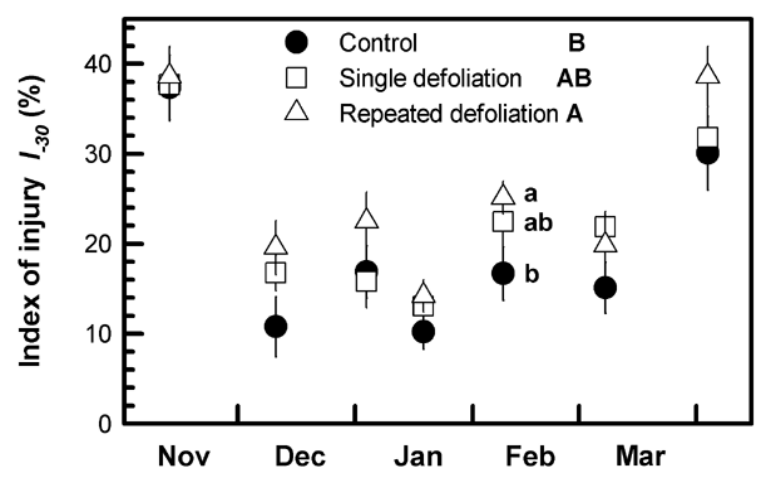

Figure 3. Index of injury $\left(I_{-30}\right)$ after artificial freezing $\left(-30{ }^{\circ} \mathrm{C}\right)$ of bark tissue from 20 -year-old pedunculate oaks, which had been subjected to different defoliation treatments (closed circles, control; open squares, single defoliation; open triangles, repeated defoliation). High values of $I_{-30}$ indicate low frost hardiness and vice versa. Different lower case letters indicate significant differences between the treatments on a given date. For the entire investigation period, $I_{-30}$ values of repeatedly defoliated oaks were significantly higher than those of control trees (indicated by different upper case letters in the legend; ANOVA with repeated measurement analysis).

treatment did not differ significantly from that of control or RD trees. Therefore, chemical analyses of the bark tissue were confined to samples from control and repeatedly defoliated oaks.

\subsection{Chemical analyses}

In July 2000, foliar $\mathrm{N}$ concentrations and $\mathrm{C}: \mathrm{N}$ ratios did not differ significantly among the treatments, and the $\mathrm{N}$ concentrations were within the range of "adequate" $N$ nutrition of pedunculate oak plantations (21-28 $\mathrm{mg} \mathrm{N} \cdot \mathrm{g}^{-1}$ D.M. [48, 49]), i.e. within a range where growth increase will only occur after high rates of $\mathrm{N}$ application. However, $\mathrm{N}$ concentrations were lower, and $\mathrm{C}: \mathrm{N}$ ratios higher, in the bark of repeatedly defoliated oaks compared to the control trees on most of the sampling dates including the date in February, on which the differences in $I_{-30}$ between $\mathrm{C}$ and RD trees were significant (Fig. 4). For N concentrations and $\mathrm{C}: \mathrm{N}$ ratios, the difference between $\mathrm{C}$ and RD trees was also significant for the entire investigation period.

The predominate soluble sugar compounds in the bark tissue were fructose, glucose and sucrose, with concentrations between approx. 20 and more than $100 \mathrm{mmol} \cdot \mathrm{kg}^{-1}$ D.M. The concentrations 

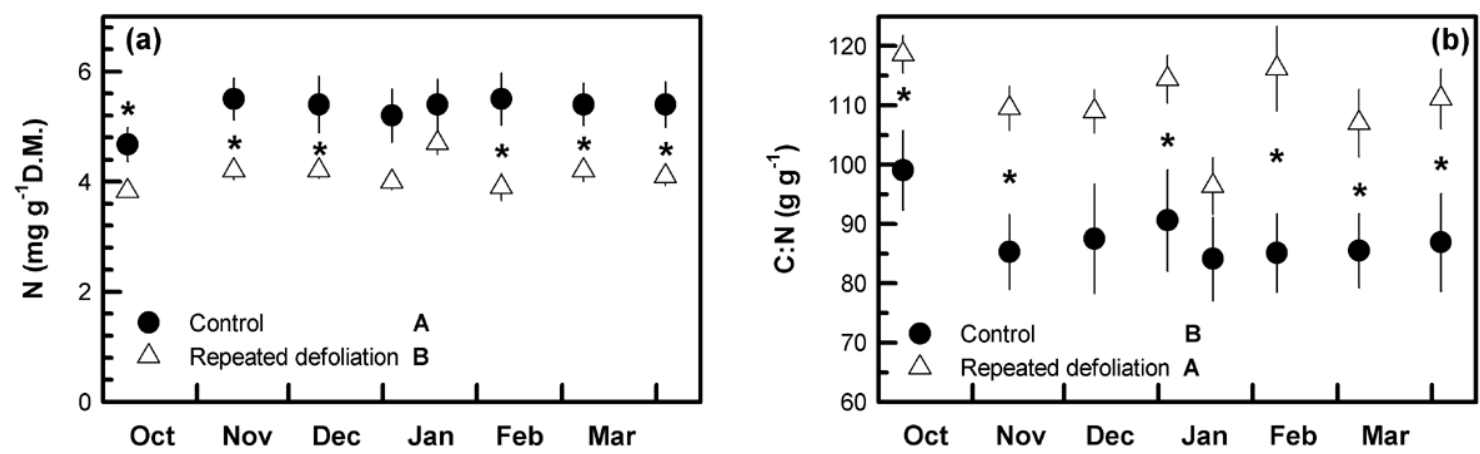

Figure 4. Nitrogen concentrations (a) and C:N ratios (b) of bark tissue from non-defoliated (control, closed circles) and repeatedly defoliated (open triangles) 20-year-old pedunculate oaks. Asterisks indicate significant differences between the treatments on a given date. For the entire investigation period, bark $\mathrm{N}$ concentrations of repeatedly defoliated oaks were significantly lower, and bark C:N ratios higher, than those of control trees (indicated by different upper case letters in the legend; ANOVA with repeated measurement analysis).

Table II. Results of linear correlation analyses between the index of injury at $-30{ }^{\circ} \mathrm{C}\left(I_{-30}\right.$; as a measure of frost hardiness) of the bark tissue as the dependent variable and concentrations of individual and total soluble sugars, quercitol, $\mathrm{N}$ and $\mathrm{C}: \mathrm{N}$ as independent variables. The analyses were calculated for the entire investigation period (October-April), and for the period with the lowest temperatures (January-February). $n$, number of samples; $r$, correlation coefficient. Bold $P$ values indicate significant correlation.

\begin{tabular}{|c|c|c|c|c|c|c|}
\hline \multirow{2}{*}{ Compound } & \multicolumn{3}{|c|}{ October-April } & \multicolumn{3}{|c|}{ January-February } \\
\hline & $n$ & $r$ & $P$ & $n$ & $r$ & $P$ \\
\hline Stachyose & 83 & -0.668 & $<0.0001$ & 35 & -0.535 & 0.0009 \\
\hline Glucose & 95 & -0.416 & $<0.0001$ & 35 & -0.162 & 0.354 \\
\hline Sucrose & 95 & -0.407 & $<0.0001$ & 35 & -0.351 & 0.039 \\
\hline Raffinose & 95 & -0.406 & $<0.0001$ & 35 & -0.451 & 0.0065 \\
\hline Fructose & 95 & -0.393 & $<0.0001$ & 35 & -0.312 & 0.068 \\
\hline Soluble sugars & 95 & -0.528 & $<0.0001$ & 35 & -0.394 & 0.0191 \\
\hline $\mathrm{N}$ & 95 & -0.313 & 0.002 & 35 & -0.513 & 0.0016 \\
\hline $\mathrm{C}: \mathrm{N}$ & 95 & 0.328 & 0.001 & 35 & 0.563 & 0.0004 \\
\hline Quercitol & 95 & -0.173 & 0.093 & 35 & -0.280 & 0.1036 \\
\hline
\end{tabular}

of raffinose and stachyose were considerably lower. The concentrations of the soluble sugars exhibited a typical course during winter, increasing from November to January, February or March, and decreasing thereafter (Fig. 5). The only exception is sucrose whose concentration already was high in October, and did not differ significantly among the sampling dates. Interestingly, no significant differences were found between the control trees and the repeatedly defoliated oaks except for raffinose and stachyose, whose concentrations were lower in the bark of the RD trees on some (stachyose) or all (raffinose) sampling dates.

Of the cyclitols investigated in bark tissue, only quercitol was present in concentrations that were high enough for quantitative evaluation. The quercitol concentrations were between 8 and $33 \mathrm{mmol} \cdot \mathrm{kg}^{-1}$ D.M. and exhibited an increase from the beginning of October to mid-November, but then remained on a more or less constant level until April (Fig. 6). On all sampling dates but the last one (beginning of April), the quercitol concentrations were significantly lowered in the repeatedly defoliated oaks.

\subsection{Relationships between chemical components and frost hardiness}

The total sugar concentrations were negatively correlated with the $I_{-30}$ values (Tab. II). This was true for the entire investigation period from October to April as well as for the period with the lowest temperatures (January-February), and indicates a decrease in frost hardiness with decreasing sugar concentrations (Fig. 7). For the whole study period, significant negative correlations were also obtained for the single sugar compounds, the strongest one for stachyose, the weakest for fructose (Tab. II). Weaker, but still significant correlations were detected between $I_{-30}$, on the one hand, and $\mathrm{N}$ and $\mathrm{C}: \mathrm{N}$, on the other. In January and February, these correlations were even closer in contrast to those of glucose and fructose, whose concentrations were rather constant during that period. No significant correlation was found between $I_{-30}$ and quercitol.

The multiple correlation for predicting $I_{-30}$ from the concentrations of $\mathrm{N}$ and organic compounds, $\mathrm{C}: \mathrm{N}$ ratios and defoliation during the entire investigation period shows that $45 \%$ of the total variation could be explained solely by stachyose concentration 

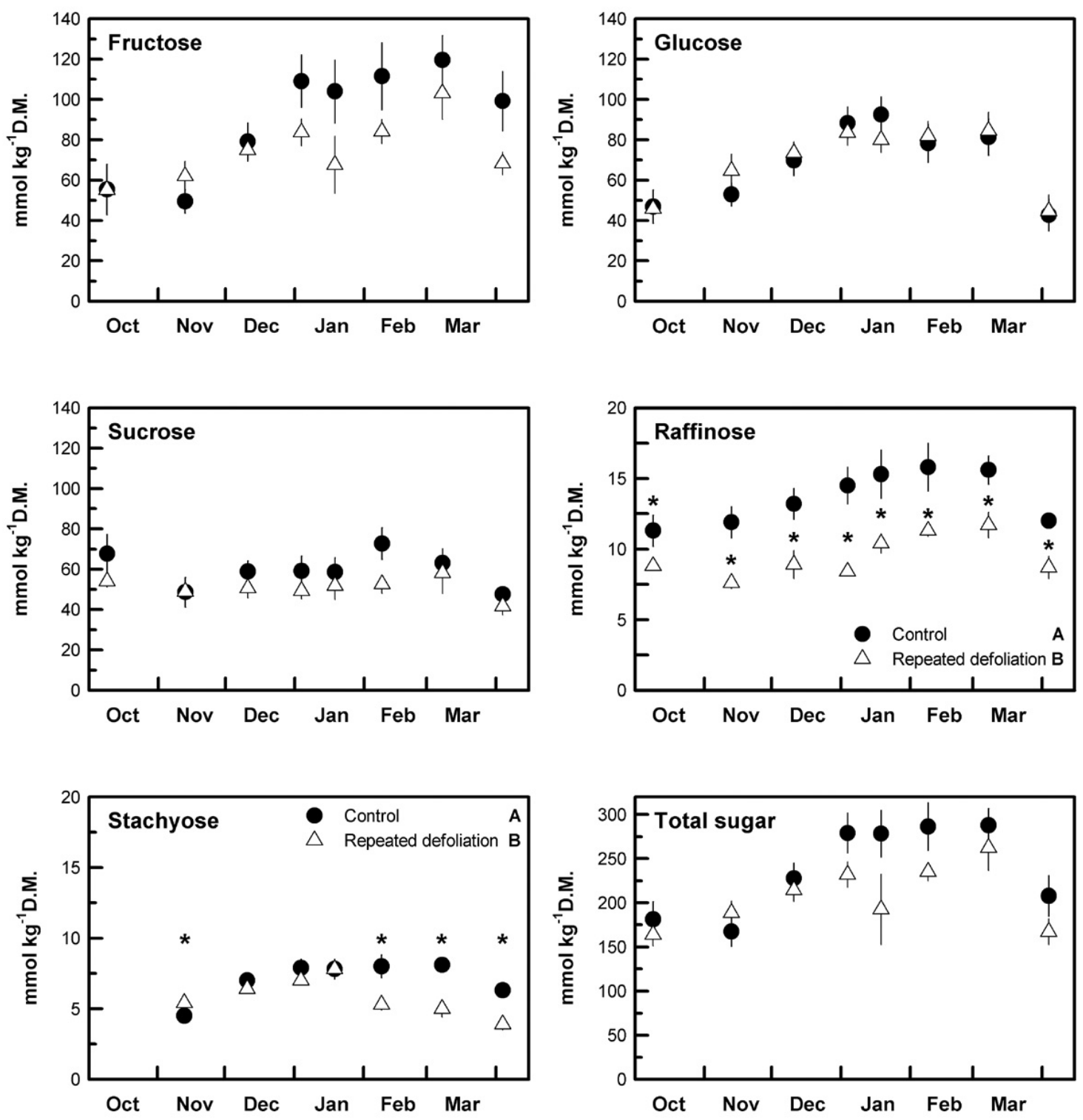

Figure 5. Concentrations of different soluble sugars, and of the cumulative amount of these sugars, in bark tissue of non-defoliated (control, closed circles) and repeatedly defoliated 20-year-old pedunculate oaks (open triangles). Asterisks indicate significant differences between the treatments on a given date. For the entire investigation period, raffinose and stachyose concentrations of repeatedly defoliated oaks were significantly lower than those of control trees (indicated by different upper case letters in the legend; ANOVA with repeated measurement analysis).

(Tab. III). The multiple correlation coefficient was significantly raised to 0.53 by including the cumulative amount of soluble sugars into the model, but could not be significantly increased by considering further variables.

\section{DISCUSSION}

Frost causes damage to plant tissue primarily by two mechanisms [4, 38, 51]: (1) by the formation of ice within cells and (2) by cell dehydration due to the large difference in the water potential between the unfrozen cell content and the intercellular space, which contains extraplasmatic ice. Under natural con- ditions, bark, leaves and vegetative buds of freezing-tolerant angiosperms survive freezing temperatures lower than $-10{ }^{\circ} \mathrm{C}$ to $-15^{\circ} \mathrm{C}$ only if freezing is confined to the extracellular space [38]. Damaging effects due to severe dehydration can be prevented and, thereby, frost resistance increased by an accumulation of cryoprotective compounds such as sugars in the cells. The correlation of frost hardiness during winter with the concentration of sugars in the tissues, at least during frost hardening, is a common feature of various organs of deciduous woody species (rhizomes of Rubus chamaemorus [22]; shoots of Salix viminalis, Cornus florida, Rhus typhina, Robinia pseudoacacia $[31,33])$. The marked seasonal course of the concentrations of total and individual sugars (except for sucrose) with an increase 
Table III. Results of multiple correlation analysis among the index of injury at $-30{ }^{\circ} \mathrm{C}\left(I_{-30}\right.$; as a measure of frost hardiness $)$ of the bark tissue as the dependent variable, and concentrations of fructose, glucose, raffinose, stachyose, sucrose, soluble sugars (sum of fructose, glucose, raffinose, stachyose and sucrose), quercitol, N, C:N ratio and defoliation as predictor variables (selected models), computed for the entire investigation period. Number of samples $=83$. The increase of the multiple determination coefficient $R^{2}$ with stepwise inclusion of additional predictor variables is shown. All $R^{2}$ values are significant at $P<0.001$. Different lower case letters indicate a significant increase in $R^{2}$ by including additional variables into the model.

\begin{tabular}{lc}
\hline Predictor variable & $R^{2}$ \\
\hline Stachyose & $0.446 \mathbf{a}$ \\
Stachyose, soluble sugars & 0.531 b \\
Stachyose, soluble sugars, fructose & $0.548 \mathbf{b}$ \\
Stachyose, soluble sugars, fructose, C:N & $0.552 \mathbf{b}$ \\
Stachyose, soluble sugars, fructose, C:N, N & 0.568 b \\
Stachyose, soluble sugars, fructose, C:N, N, quercitol, raffinose, glucose, defoliation & 0.575 b \\
\hline
\end{tabular}

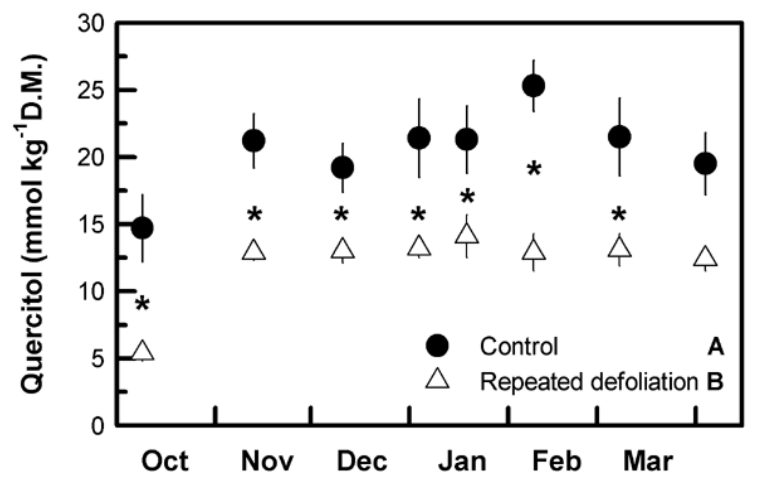

Figure 6. Quercitol concentrations in the bark of non-defoliated (control, closed circles) and repeatedly defoliated 20 -year-old pedunculate oaks (open triangles). Asterisks indicate significant differences between the treatments on a given date. For the entire investigation period, quercitol concentrations of repeatedly defoliated oaks were significantly lower than those of control trees (indicated by different upper case letters in the legend; ANOVA with repeated measurement analysis).

until mid-winter and a decrease thereafter (Fig. 5), as well as the significant correlations between sugar concentrations and the index of frost injury $\left(I_{-30}\right.$; Fig. 7 and Tab. II) in the bark of Quercus robur, fit those observations well. The fact that the concentrations of sucrose only exhibited slight seasonal variations may be related to the sugar's fundamental role in carbohydrate transport $[1,20]$. Sugars can function as cryoprotectants, which can non-specifically dilute the concentrations of compounds that are potentially toxic to proteins and membranes below the critical threshold of inactivation [39, 51]. In addition to this "colligative" effect, a more specific "non-colligative" effect has been postulated. This effect relies on interactions between the cryoprotectant and the biomolecule, or on the prevention of water crystallization in the vicinity of biomolecules [39]. In this regard, di- and trisaccharides seem to be more effective than monosaccharides [11]. This might explain the fact that, in the present investigation, the correlation of $I_{-30}$ was closest with the concentration of the tetrasaccharide stachyose; despite of its relatively low amount per unit dry matter.

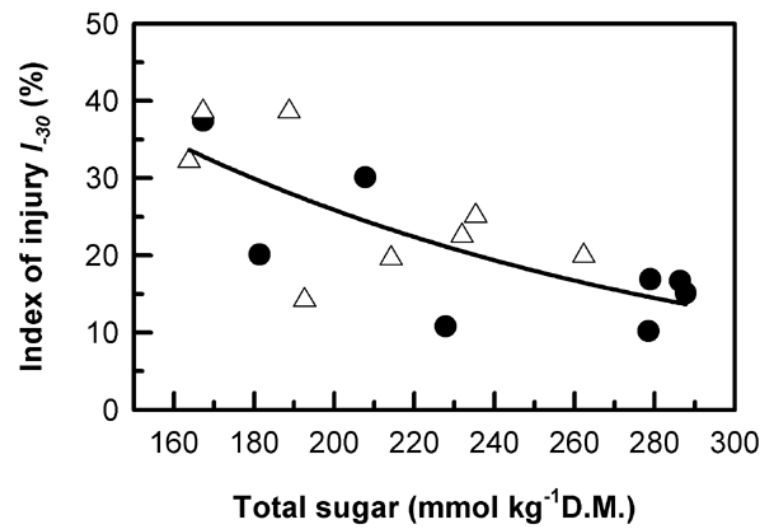

Figure 7. Index of injury after artificial freezing $\left(-30{ }^{\circ} \mathrm{C}\right)$ plotted against the total sugar concentration of bark tissue from 20-year-old pedunculate oaks. Mean values of each sampling date for repeatedly defoliated (open triangles) and control trees (closed circles). The regression (exponential decay) was calculated for the combined data set of both treatments $\left(r^{2}=0.527 ; P<0.002\right)$.

In $Q$. robur, defoliation in spring causes loss of photosynthate, resulting in a reduced formation of latewood [5, 36]. In $Q$. petraea, a significant correlation was found between defoliation intensity and latewood increment [6]. Accordingly, the relative growth increment in the stem diameter of our repeatedly defoliated (RD) pedunculate oaks was significantly lower than that of the control trees (Tab. I).

Compared to the control trees, repeated defoliation resulted in significantly higher $I_{-30}$ values, when the entire cold season is considered: this indicates reduced frost hardiness. Although the amount of photosynthate must have been considerably reduced in the repeatedly defoliated oaks as was indicated by the decrease in their growth increment, the concentrations of the sugars that occur in the bark in higher quantities (fructose, glucose, sucrose) remained unaffected. Thus, it can be concluded that the decrease in frost hardiness of the RD trees was not due to a reduction in the concentrations of these sugar compounds. In contrast, the concentrations of raffinose and stachyose that occur in relatively low amounts in the bark were significantly 
reduced on some (stachyose) or all (raffinose) measurement dates. A reduction in the concentrations of these sugars could have impaired the frost hardiness of the RD trees since those compounds have specific cryoprotective features (see above), and, additionally, since they can enhance the cryoprotective effect of sugars such as sucrose by inhibiting their crystallization. Such an effect has been found for raffinose [10]. Raffinose concentrations, which were found to exhibit pronounced differences between minimum values in summer and maximum values in winter [43], have also been linked to frost hardiness in the stem tissue of Cornus sericea [3], in the leaves of Eucalyptus gunnii [4] and in the apical buds of Picea abies [28]. According to Stushnoff et al. (1997) [43], raffinose and stachyose are generally associated with cold hardiness, particularly in cold-hardy woody plant taxa. In our study, the dates of reduced raffinose and stachyose concentrations in the bark of the RD trees include the period, in which the frost hardiness was significantly lowered in these trees (cf. Figs. 3 and 5). This points towards a defoliation-induced reduction in the concentrations of those sugars as a cause of diminished frost hardiness.

Cyclitols have also been assumed to act as cryoprotectants [34]. In $Q$. robur, quercitol is the dominating cyclitol. It is found in leaves, twigs, bark and buds and contributes up to $65 \%$ to the neutral fraction and up to $3.3 \%$ to dry matter [35]. In contrast to other cyclitols such as ononitol, pinitol and quebrachitol, the cryoprotective effect of quercitol does not seem to be a specific, non-colligative one [32]; thus, its effect is likely to depend on its concentration. In our study, repeated defoliation significantly reduced the quercitol concentration of the bark on all but the last measurement date (at the beginning of April; Fig. 6). However, there were no significant correlations between the frost hardiness ( $I_{-30}$ values) of the bark tissue and its dry matter-related quercitol content. Therefore, we have no clear evidence that a reduction in the quercitol concentration contributes to the defoliation-induced decrease in frost hardiness.

Nitrogen-containing compounds may also be involved in frost hardiness. Although there is, in general, no close relationship between the amino acid concentration and frost hardiness, particular amino acids such as arginine and proline can play an important role in freezing tolerance $[38,51]$. In addition, the occurrence of soluble cryoprotective plant proteins in freezingtolerant plants has been postulated [17]. Cryoprotective proteins have been found in Arabidopsis thaliana [42] and Hordeum vulgare [9]. In our study, $\mathrm{N}$ concentrations were significantly lower in the bark of the RD trees than in the control oaks (Fig. 4), and were lower than $\mathrm{N}$ concentrations in the bark of the adult $Q$. robur trees $\left(5.43 \pm 0.24 \mathrm{mg} \cdot \mathrm{g}^{-1} \mathrm{D} . \mathrm{M}\right.$. $)$ that were adequately supplied with $\mathrm{N}$ as determined by foliar $\mathrm{N}$ concentrations [45]. In the bark of mature beech trees (Fagus sylvatica) growing on acidic soils in Southern Sweden, the range of $\mathrm{N}$ concentrations also was slightly higher $\left(5.5-7.0 \mathrm{mg} \cdot \mathrm{g}^{-1}\right.$ D.M.; [21]). In our investigation, the decrease in $\mathrm{N}$ concentration in the bark of the RD trees may have been caused by reduced $\mathrm{N}$ uptake as a consequence of decreased fine root production after defoliation - a reduction in fine-root biomass after defoliation of $Q$. robur has been found, e.g., by Block et al. (1995) [7] and Gieger and Thomas (2002) [14]. Although the overall correlations between $\mathrm{N}$ or $\mathrm{C}: \mathrm{N}$, respectively, and $I_{-30}$ were not very tight, and although $\mathrm{N}$ and $\mathrm{C}: \mathrm{N}$ did not contribute much to explain the variation of the multiple correlation among chem- ical components and $I_{-30}$, our results might be a first hint that a reduction in the concentration of nitrogenous compounds is involved in the defoliation-induced decrease in frost hardiness. More detailed analyses are necessary to elucidate this role of nitrogenous compounds.

We conclude that the significantly reduced frost hardiness of the bark of the repeatedly defoliated pedunculate oaks is mainly due to the decrease in the concentrations of the sugars raffinose and stachyose, which are generally able to increase frost hardiness by means of specific non-colligative effects even at low concentrations. In addition, the decrease in $\mathrm{N}$ compounds may have contributed to the reduction in frost hardiness, but this has to be corroborated by further studies. The decrease in the concentrations of all these compounds lies within a period of significantly reduced frost hardiness in the repeatedly defoliated trees, and within a period in which subzero temperatures down to $-24{ }^{\circ} \mathrm{C}$ did occur in severe winters in that region in the past [19] - such temperatures have not been reached during our study and, therefore, freezing injury to the oaks did not occur. Through the reduction in the concentrations of sugars (particularly those of raffinose and stachyose) and, perhaps, through an additional reduction of the concentrations of $\mathrm{N}$ compounds, repeated defoliation decreases the capability of the bark to acclimatize to winter frost. Thus, the hypothesis that a defoliation-induced reduction of frost hardiness of the bark is part of the causal complex in the occurrence of increased oak mortality [47] can still be considered valid.

Acknowledgments: We thank Dr. Günter Hartmann and Dipl.Forstw. Ratburg Blank, Forest Research Station of Lower Saxony, Dept. Forest Protection, for their co-operation in defoliating the trees; Mr. Schäfer-Wildenberg from tree nursery H.G. Rahte (Wietze, Lower Saxony) for providing the research facilities on the ground of the nursery; Dr. Eberhard Fritz, Institute of Forest Botany, University of Göttingen, for his kind support in lyophilization of the bark samples, and M.Sc. Sabine Maringer, Department of Chemical Physiology of Plants, Institute of Ecology and Conservation Biology, University of Vienna, for valuable assistance with gas chromatography.

\section{REFERENCES}

[1] Alaoui-Sossé B., Parmentier C., Dizengremel P., Barnola P., Rhythmic growth and carbon allocation in Quercus robur. 1. Starch and sucrose, Plant Physiol. Biochem. 32 (1994) 331-339.

[2] Alberdi M., Corcuera L.J., Cold acclimation in plants, Phytochemistry 30 (1991) $3177-3184$

[3] Ashworth E.N., Stirm V.E., Volenec J.J., Seasonal variations in soluble sugars and starch within woody stems of Cornus sericea L., Tree Physiol. 13 (1993) 379-388.

[4] Beck E., Hansen J., Heim R., Schäfer C., Vogg G., Leborgne N., Teulieres C., Boudet A.M., Cold hardening and dehardening of trees, in: Sandermann H. Jr., Bonnet-Masimbert M. (Eds.), Eurosilva Contribution to forest tree physiology, INRA, Paris, 1994, pp. 171193.

[5] Blank R., Ringporigkeit des Holzes und häufige Entlaubung durch Insekten als spezifische Risikofaktoren der Eichen, Forst Holz 52 (1997) 235-242.

[6] Blank R., Riemer T., Quantifizierung des Einflusses blattfressender Insekten auf den Spätholzzuwachs der Eiche in Nordwestdeutschland, Forst Holz 54 (1999) 569-576.

[7] Block J., Delb H., Hartmann G., Seemann D., Schröck H.W., Schwere Folgeschäden nach Kahlfraß durch Schwammspinner im Bienwald, Allg. Forst Z. / Der Wald 50 (1995) 1278-1281. 
[8] BMELF (Bundesministerium für Ernährung, Landwirtschaft und Forsten) (Ed.), Bundesweite Bodenzustandserhebung im Wald (BZE) - Arbeitsanleitung, BMELF, Bonn, 1990.

[9] Bravo L.A., Gallardo J., Navarrete A., Olave N., Martínez J., Alberdi M., Close T.J., Corcuera L.J., Cryoprotective activity of a coldinduced dehydrin purified from barley, Physiol. Plant. 118 (2003) 262-269.

[10] Caffrey M., Fonseca V., Leopold A.C., Lipid-sugar interactions, Plant Physiol. 86 (1988) 754-758.

[11] Crowe J.H., Carpenter J.F., Crowe L.M., Anchordoguy T.J., Are freezing and dehydration similar stress vectors? A comparison of modes of interaction of stabilizing solutes with biomolecules, Cryobiology 27 (1990) 219-231.

[12] Deutscher Wetterdienst, Monatlicher Witterungsbericht, Deutscher Wetterdienst, Offenbach, Germany, 2001.

[13] Flint H.L., Boyce B.R., Beattie D.J., Index of injury - a useful expression of freezing injury to plant tissues as determined by the electrolytic method, Can. J. Plant Sci. 47 (1967) 229-230.

[14] Gieger T., Thomas F.M., Effects of defoliation and drought stress on biomass partitioning and water relations of Quercus robur and Quercus petraea, Basic Appl. Ecol. 3 (2002) 171-181.

[15] Gray G.R., Chauvin L.-P., Sarhan F., Huner N.P.A., Regulation of cold acclimation, in: Li P.H., Chen T.H.H. (Eds.) Plant Cold Hardiness - Molecular Biology, Biochemistry, and Physiology, Plenum Press, New York and London, 1997, pp. 181-190.

[16] Große-Schulte T., Zusammenhänge zwischen Quercit-Speicherung und Frosthärte in der Gattung Quercus, Diploma Thesis, Univ. Münster, Institute of Plant Ecology, 1995.

[17] Guy C.L., Cold acclimation and freezing stress tolerance: role of protein metabolism, Annu. Rev. Plant Physiol. Plant Mol. Biol. 41 (1990) 187-223.

[18] Hartmann G., Ursachenanalyse des Eichensterbens in Deutschland - Versuch einer Synthese bisheriger Befunde, Mitt. Biol. Bundesanst. Land- u. Forstwirtsch. Berlin-Dahlem 318 (1996) 125-151.

[19] Hartmann G., Blank R., Winterfrost, Kahlfraß und Prachtkäferbefall als Faktoren im Ursachenkomplex des Eichensterbens in Norddeutschland, Forst Holz 47 (1992) 443-452.

[20] Heizmann U., Kreuzwieser J., Schnitzler J.-P., Brüggemann N., Rennenberg H., Assimilate transport in the xylem sap of pedunculate oak (Quercus robur) saplings, Plant Biol. 3 (2001) 132-138.

[21] Jönsson A.M., Mineral nutrients of beech (Fagus sylvatica) bark in relation to frost sensitivity and soil treatments in southern Sweden, Ann. For. Sci. 57 (2000) 1-8.

[22] Kaurin Å., Junttila O., Hansen J., Seasonal changes in frost hardiness in cloudberry (Rubus chamaemorus) in relation to carbohydrate content with special reference to sucrose, Physiol. Plant. 52 (1981) 310 314.

[23] Kolb T.E., Steiner K.C., Barbour H.F., Seasonal and genetic variations in loblolly pine cold tolerance, For. Sci. 31 (1985) 926-932.

[24] Kosola K.R., Dickmann D.I., Paul E.A., Parry D., Repeated insect defoliation effects on growth, nitrogen acquisition, carbohydrates, and root demography of poplars, Oecologia 129 (2001) 65-74.

[25] Landmann G., Becker M., Delatour C., Dreyer E., Dupouey J.-L., 1993. Oak dieback in France: historical and recent records, possible causes, current investigations, in: Bayerische Akademie der Wissenschaften (Ed.) Zustand und Gefährdung der Laubwälder, Rundgespräche der Kommission für Ökologie 5, F. Pfeil, Munich, Germany, 1993, pp. 97-113.

[26] Li C., Junttila O., Ernstsen A., Heino P., Palva E.T., Photoperiodic control of growth, cold acclimation and dormancy development in silver birch (Betula pendula) ecotypes, Physiol. Plant. 117 (2003) 206-212.

[27] Li P.H., Chen T.H.H., Plant Cold Hardiness - Molecular Biology, Biochemistry, and Physiology, Plenum Press, New York and London, 1997.

[28] Lipavská H., Svobodová H., Albrechtová J., Annual dynamics of the content of non-structural saccharides in the context of structural development of vegetative buds of Norway spruce, J. Plant Physiol. 157 (2000) 365-373.
[29] Lobinger G., Zusammenhänge zwischen Insektenfraß, Witterungsfaktoren und Eichenschäden, Bayerische Landesanstalt für Wald und Forstwirtschaft, Freising, Germany, 1999.

[30] Murray M.B., Cape J.N., Fowler D., Quantification of frost damage in plant tissues by rates of electrolyte leakage, New Phytol. 113 (1989) 307-311.

[31] Ögren E., Fall frost resistance in willows used for biomass production. II. Predictive relationships with sugar concentration and dry matter content, Tree Physiol. 19 (1999) 755-760.

[32] Orthen B., Popp M., Cyclitols as cryoprotectants for spinach and chickpea thylakoids, Environ. Exp. Bot. 44 (2000) 125-132.

[33] Parker J., Seasonal changes in cold resistance and free sugars of some hardwood tree barks, For. Sci. 8 (1962) 255-262.

[34] Popp M., Smirnoff N., Polyol accumulation and metabolism during water deficit, in: Smirnoff N. (Ed.) Environment and plant metabolism - Flexibility and acclimation, Bios Scientific Publishers, Oxford, 1995, pp. 199-215.

[35] Popp M., Lied W., Bierbaum U., Gross M., Große-Schulte T., Hams S., Oldenettel J., Schüler S., Wiese J., Cyclitols - Stable osmotica in trees, in: Rennenberg H., Eschrich W., Ziegler H. (Eds.), Trees Contributions to modern tree physiology, Backhuys Publishers, Leiden, The Netherlands, 1997, pp. 257-270.

[36] Rubtsov V.V., Influence of repeated defoliations by insects on wood increment in common oak (Quercus robur L.), Ann. Sci. For. 53 (1996) 407-412.

[37] Sachs L., Applied statistics - A handbook of techniques, 2nd ed., Springer-Verlag, New York, 1984.

[38] Sakai A., Larcher W., Frost survival of plants, Ecological Studies 62, Springer-Verlag, Berlin, 1987.

[39] Santarius K.A., The mechanism of cryoprotection of biomembrane systems by carbohydrates, in: Li P.H., Sakai A. (Eds.), Plant cold hardiness and freezing stress - Mechanisms and crop implications, Vol. 2, Academic Press, New York, 1982, pp. 475-486.

[40] Shapiro S.S., Wilk M.B., An analysis of variance test for normality (complete samples), Biometrika 52 (1965) 591-611.

[41] Siwecki R., A decline of oak forests caused by abiotic and biotic factors and attempts at biological research in this syndrome, Arbor. Korn. 34 (1989) 161-169.

[42] Steponkus P.L., Uemura M., Joseph R.A., Gilmour S.J., Thomashow M.F., Mode of action of the COR15a gene on the freezing tolerance of Arabidopsis thaliana, Proc. Natl. Acad. Sci. USA 95 (1998) 14570-14575.

[43] Stushnoff C., Seufferfeld M.J., Creegan T., Oligosaccharides as endogenous cryoprotectants in woody plants, in: Li P.H., Chen T.H.H. (Eds.), Plant cold hardiness - Molecular biology, biochemistry, and physiology, Plenum Press, New York and London, 1997, pp. 301-309.

[44] Thomas F.M., Ahlers U., Effects of excess nitrogen on frost hardiness and freezing injury of above-ground tissue in young oaks (Quercus petraea and Q. robur), New Phytol. 144 (1999) 73-83.

[45] Thomas F.M., Blank R., The effect of excess nitrogen and of insect defoliation on the frost hardiness of bark tissue of adult oaks, Ann. Sci. For. 53 (1996) 395-406.

[46] Thomas F.M., Blank R., Hartmann G., Der Einfluß von Stammexposition, Stickstoff-Status und Blattfraß auf die Frosthärte des Bastes von Alteichen, Verh. Ges. Ökol. 26 (1996) 153-160.

[47] Thomas F.M., Blank R., Hartmann G., Abiotic and biotic factors and their interactions as causes of oak decline in Central Europe, For. Pathol. 32 (2002) 277-307.

[48] Van den Burg J., Foliar analysis for determination of tree nutrient status - a compilation of literature data, Rapport No. 414, Rijksinstituut voor Onderzoek in de Bos- en Landschapsbouw "De Dorschkamp", Wageningen, The Netherlands, 1985.

[49] Van den Burg J., Foliar analysis for determination of tree nutrient status - a compilation of literature data. 2. Literature 1985-1989, Rapport No. 591, "De Dorschkamp", Institute for Forestry and Urban Ecology, Wageningen, The Netherlands, 1990.

[50] Wargo P.M., Consequences of environmental stress on oak: predisposition to pathogens, Ann. Sci. For. 53 (1996) 359-368.

[51] Xin Z., Browse J., Cold comfort farm: the acclimation of plants to freezing temperatures, Plant Cell Environ. 23 (2000) 893-902. 